\title{
Transformational Leadership in Planning Curricula
}

\author{
Beth Nagy, David J. Edelman \\ University of Cincinnati, Cincinnati, USA \\ Email: nagybet@yahoo.com, edelmadj@ucmail.uc.edu
}

Received 7 July 2014; revised 9 August 2014; accepted 4 September 2014

Copyright (C) 2014 by author and Scientific Research Publishing Inc.

This work is licensed under the Creative Commons Attribution International License (CC BY). http://creativecommons.org/licenses/by/4.0/

C) (i) Open Access

\begin{abstract}
Planners are expected to be ethical, advancing socially-responsible citizenship-based practices. They must also have a keen understanding of the implications of top-down policy decisions on communities. A Planner is a public servant. Public servants require a mastery of techniques for community engagement: involving a wide range of people in making decisions, an ability to work with the public and articulate planning issues to a wide variety of audiences, as well as the ability to function as a facilitator when community interests conflict. These skills call for a theoretical foundation in transformational leadership, but students will not learn transformational leadership unless the curriculum deliberately teaches and models it. This research considers the intersection of three major themes in the pedagogy of Planning: sustainable communities, transformational leadership, and community engagement. The intersection, a critical Planning pedagogy, should be a guiding principle of all Planning curricula. Although this is a case study, and its findings limited to one program, the framework can be explored as a means to examining transformational leadership as a means to advancing socially-responsible citizenship-based practices in Planning curricula.
\end{abstract}

\section{Keywords}

Critical Planning Pedagogy, Transformational Leadership, Community Engagement

\section{Introduction}

This research considers the intersection of three major themes in the pedagogy of Planning education: sustainable communities, transformational leadership and community engagement. The intersection, a critical Planning pedagogy, should be a guiding principle of all Planning curricula. This democratic, community-based learning pedagogy seeks to build and sustain communities with a high quality of life for all citizens by balancing technical Planning skills with socially responsible, ethical processes. 
Higher education, through colleges and universities, plays a key role in the development of student experience and learning related to community engagement and leadership. According to the Kettering Foundation (2011), "a central goal of higher education is to help make democracy possible by preparing citizens for public life." This philosophy asks faculty, administration and staff to be "part of a movement to strengthen higher education's democratic mission and foster a more democratic culture throughout American society" (2011). Conversely, society looks to institutions of higher education to provide a framework for learning and practicing socially responsible citizenship. According to Block (2008):

A citizen is one who is willing to hold oneself accountable for the well-being of the larger collective of which we are a part. Citizens choose to own and exercise power rather than defer or delegate it to others. We enter into a collective possibility that gives hospitable and restorative community its own sense of being. Citizens acknowledge that community grows out of the possibility of citizens. Community is built not by specialized expertise, or great leadership, or improved services; it is built by great citizens that use the asset-based community development framework, incorporating the gifts and capacities of all others, and act to bring the gifts of those at the margin into the center (2008).

Planning programs are expected to uphold the integrity of the Planning profession by demonstrating socially responsible practices. The methodology is community-based learning and community engagement. The American Planning Association or APA (APA, 2010), the American Institute of Certified Planners or AICP (AICP, 2010), the Planning Accreditation Board or PAB (PAB, 2006) and the Association of Collegiate Schools of Planning or ACSP (ACSP, 2011) outline the principles to which Planning programs should aspire:

- To be conscious of the rights of others;

- To provide accurate information on planning issues to all affected persons (regardless of socio-economic status);

- To give people the opportunity to have a meaningful impact on the development of plans and programs that may affect them (participation should be broad enough to include those who lack formal organization or influence);

- To seek social justice by working to expand choice and opportunity for all persons (recognizing a special responsibility to plan for the needs of the disadvantaged);

- To urge the alteration of policies, institutions, and decisions that opposes equitable distribution of resources, and

- To deal fairly with all participants in the planning process.

Planners must be able to critically analyze problems, practices and places. Marcuse $(1976,1989,2010)$ is a major influence in advancing the idea that Planning is critical thinking and that Planning tools can be used in transformative ways. Planning has a "history of common debates about ideas and practices and is rooted in a critical concern for the 'improvement' of human and environmental well-being” (Hillier \& Healy, 2008). The Planning process is the type of critical thinking used by civic leaders, community activists, involved citizens and professionals to improve various aspects of their communities (APA, 2010).

Community engagement is a process that allows the student to apply his or her professional skills in partnership with a community. According to Fawcett et al. (1995):

Community engagement is the process of working collaboratively with and through groups of people affiliated by geographic proximity, special interest, or similar situations to address issues affecting the well-being of those people. It is a powerful vehicle for bringing about environmental and behavioral changes that will improve the health of the community and its members. It often involves partnerships and coalitions that help mobilize resources and influence systems, change relationships among partners, and serve as catalysts for changing policies, programs, and practices” (1995).

Planning is inherently transformational and implies the ability to lead. "It builds within the community critical thinking and planning abilities so that development projects and planning processes can be replicated by community members in the future. A good planning project should leave a community not just with more immediate "products," but also with an increased capacity to meet future needs. In other words, a quality and sustainable product depends on a quality and sustainable process" (Kennedy, 2009: p. 9). Planning programs are expected to prepare students to understand their roles working in communities, as technical assistance providers facilitating sustainable practices, structurally and socially. This requires the ability to lead sustainable processes, to embrace transformational leadership practices, and to seek to provide ethical assistance.

Transformational leadership opportunities provide the type of process-based skills Planners need to work with 
communities. Transformational leadership behaviors include building vision and goals, providing intellectual stimulation, offering individualized support, symbolizing professional practices and values, demonstrating high performance expectations and developing structures to foster participation in decisions (Kennedy, 1996). These skills link back to the socially responsible principles of Planning (AICP, 2005) and to the type of leadership a Planning program should embrace and provide, in partnership with its university.

The three core values of the University selected for this research are citizenship, leadership and partnership ${ }^{1}$. Listing them as core values implies that the University has a stake in advancing these goals within its educational framework. Aligning with Block's definition of a citizen, the University states, "Citizenship is the ability to apply knowledge and skills for responsible civic life and action. The University's emphasis is on public engagement and ethical purpose". The University further asserts, "Leadership is motivating others to take actions that would not otherwise have been taken. Leadership is measured by the extent to which an individual or groups of individuals can influence and energize the ideas, actions and capabilities of others toward the betterment of society". This research advances the notion that co-curricular and extra-curricular transformational leadership experiences build the leadership abilities of students.

Planners need to be able to work together, and with a variety of stakeholders and constituents. This requires knowing about collaboration and partnership. In its pillars of education, the University used for this research states, "Partnership is working collaboratively to address complex issues and problems, both within and beyond the boundaries of University" (2008). Planners cannot deal with community problems by working in isolation. By working collaboratively, students gain an understanding and appreciation of what can be accomplished together that could not have been accomplished alone. This also acknowledges the importance of diversity, since constructive change often occurs when individuals and groups with different identities and various priorities come together.

It is important to know more about how Planning students are being equipped with transformational, sustainable process-based skills in higher education because the future of Planning requires connected solutions. One reads and hears of "healthy communities", building "social capital" (Putnam, 2000) or "civic infrastructure" (National Civic League, 2007) and of "sustainable communities” (Local Initiatives Support Corporation, 2011). Their discussion points to "community indicators projects", "community problem-solving” or "community quality councils". The projects differ, but they are alike in their vision of creating communities that work efficiently and productively (Jacques, 1999). This is referred to as "sustainable communities"' in this research, which focuses on the process-based skills Planning students need to build sustainable communities. According to the Local Initiatives Support Corporation, sustainable communities are:

Places that offer the positive environments needed to ensure that all residents of varied income levels are provided the opportunities and tools to build assets, to participate in their communities, and to become part of the mainstream economy. They are, in effect, the embodiment of both "community" and "development"-places where human opportunity and social and economic vitality combine with a continuous process of growth, adaptation, and improvement (LISC, 2011).

Sustainable communities share common themes and concerns such as economic security, environmental protection, social justice and a commitment to the welfare of future generations (Swisher, Rezola, \& Sterns, 2009). According to Everyday Democracy (2011: p. 3), successful community plans build trust up front, involve everyone, hold facilitated dialogues, follow up, get the word out and help build social capital. Planners facilitate this process and offer technical skills to support the formulation of the product.

\section{Theoretical Framework}

Combining the ideas of Planning and transformational leadership within higher education presents a framework for Planning educators to consider as a means of preparing students for their roles in communities. Figure 1 illustrates the theory of transformational leadership in Planning. "We need to abandon the notion of a plan and embrace the notion of process... If planners can develop ways to help people to understand the interplay between agendas—economic, environmental, social—-then they'll be central to the future” (Sussman, 2011).

"Studies investigating how leadership development occurs would be invaluable not just for those involved and responsible for student leadership development, but also for people who provide leadership education for corporate, civic and community organizations” (Posner, 2004: p. 454). The hope is for the results to be used to

${ }^{1}$ For the purpose of this research, the University used as a case study remains anonymous. 


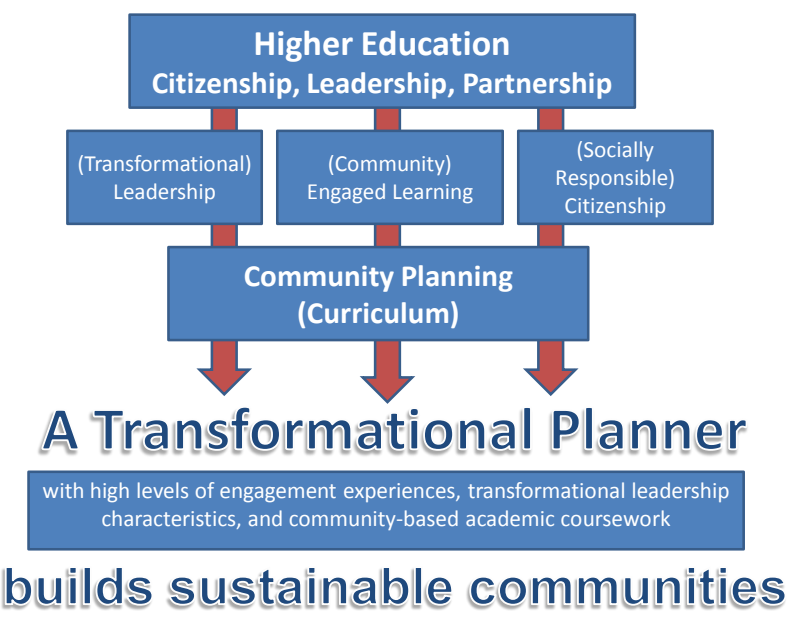

Figure 1. Transformational Planning. Source: Nagy, 2012.

inform Planning curricula.

The future of sustainable communities will lie in the hands of a new generation of leaders who are coming of age today. It is the responsibility of educators to understand the ethical imperative of preparing Planning students for the world in which they will practice-in communities. Planning educators "need to support these new leaders and empower them" (Kriesberg, 2009: p. 3) with the transformational leadership skills gained from exposure to real world experiences that model Planning ethics, critical thinking, the process, and ultimately, socially responsible citizenship.

\section{Research Context}

\subsection{Introduction}

This section reviews the theories and previous research that form the context of this study. It is divided into reviews of 1) Planning, 2) Higher Education and 3) Leadership literature. Within each, there is discussion of the theories relevant to this specific research: sustainable communities, empowerment planning, planning education, community-engaged learning, transformational leadership and student leadership development.

\subsection{Urban and Community Planning}

Planning is a strategic profession that strives to build healthy and sustainable communities by creating more convenient, equitable, healthful, efficient and attractive places for present and future generations (APA, 2010). One looks to Planning programs to provide students with the systemic and comprehensive academic support to understand, analyze, embrace, engage and empower. This is critical Planning pedagogy. According to the Association of Collegiate Schools of Planning (ACSP), its mission is to "promote education, research, service, and outreach in the United States and throughout the world by seeking to:

- Recognize diverse needs and interests in planning;

- Strengthen the role of planning education in colleges and universities through publications, conferences, and community engagement;

- Improve and enhance the accreditation process, and

- Extend planning beyond the classroom into the world of practice.

- The ACSP provides the standards for Planning education (2011). These are the criteria also used by the Planning Accreditation Board (PAB), a joint organization of the professional American Planning Association (APA) and the academic Association of Collegiate Schools of Planning (ACSP). The PAB ensures high quality education for future urban planners, and it embraces the following five core values:

- Stewardship: preserving and enhancing the knowledge base of the urban planning profession with which the Board has been entrusted;

- Collaboration: building and sustaining a bridge between the academic and practitioner communities;

- Communication: fostering awareness of urban planning education and its environment; 
- Integrity: maintaining a commitment to fairness, transparency, and consistency, and

- Leadership: maintaining currency with regard to state-of-the-art accreditation practice and instructional innovation.

APA, AICP, ACSP and PAB are all aligned in their mission of educating Planners using a balance of technical and social skills, paying special attention to the socially responsible values of the profession.

\section{Sustainable Communities}

Sustainable community development aims to improve the lives of neighborhood residents in a measurable way by bringing to bear in a tightly integrated way the power of evidence-based social interventions and the best community development strategies (LISC, 2011). To succeed, they must be based on a high level of collaboration and mutual accountability among community-based groups of many kinds, and with institutional partners. Sustainable community development is about "forces in focus" to achieve breakthrough changes in community conditions (Kubisch, 1996).

The Planner's role in building sustainable communities is to be a dynamic, community development professional embracing the standards of the profession, but also seeking to empower individuals and groups of people by providing them with the process-based skills they need to affect change in their own communities. These skills are often clustered around building socially responsible, active, political power through the formation of networks collaborating for a common agenda, in this case, to build sustainable communities. There is a high level of ethically and socially just professional practice expected of Planners, and the Planning curriculum is responsible for teaching the process, not just technical skills.

\subsection{Higher Education}

Colleges and universities have a civic mission, which includes being good institutional citizens that serve communities in multiple ways: providing forums for free democratic dialogue; conducting research on democracy, civil society, and civic development; and educating their students to be effective and responsible citizens (Wilkins, Parker, \& Dale, 2008). The objectives of leadership here should be to enhance equity, social justice and the quality of life; to expand access and opportunity; to encourage respect for differences and diversity; to strengthen democracy, civic life, and civic responsibility; and to promote cultural enrichment, creative expression, intellectual honesty, the advancement of knowledge, and personal freedom coupled with social responsibility (Talcott, 2005).

Three core values of the University in this study are citizenship, leadership, and partnership.

- Citizenship: The ability to apply knowledge and skills for responsible civic life and action. University's emphasis is on public engagement and ethical purpose.

- Leadership: Motivating others to take actions that would not otherwise have been taken. Leadership is measured by the extent to which an individual or groups of individuals can influence and energize the ideas, actions and capabilities of others toward the betterment of society.

- Partnership: Working collaboratively to address complex issues and problems, both within and beyond the boundaries of University. A university cannot solve problems by working in isolation. It must do so by interacting with others. By working in partnerships, we gain an understanding and appreciation of what can be accomplished together that could not have been accomplished alone. We also affirm the importance of diversity, since constructive change often occurs when individuals and groups with different identities and various priorities come together (University, 2010).

“An important leadership challenge for higher education is to empower students, by helping them develop those special talents and attitudes that will enable them to become effective social change agents” (Astin \& Astin, 2000: p. 12). Youniss and colleagues (1997) say that motivation comes after membership and participation, not before. During the course of participation, students incur obligations, obtain fulfillment, and develop relationships that affect their identities. They become more likely to participate in the future, suggesting that more attention should be directed to organizations and groups and the ways that students interact with them. "While students are deepening and applying the knowledge and skills they are learning, they are contributing to their communities" (Hergert, 2002: p. 195).

Students leave the university to assume leadership positions within society (Eddy et al., 1997). "If the next generation of citizen leaders is to be engaged and committed to leading for the common good, then the institu- 
tions which nurture them must [model] effective leadership” (Astin \& Astin, 2000: p. 12). American intellectual leaders continue to see schools as the cardinal organization of civic education and socialization (Addams, 1902; De Toqueville, 1838; Dewey, 1898, 1916; Iannacone \& Lutz, 1994).

The future of the community development movement will lie in the hands of a new generation of leaders who are coming of age today. These leaders are less beholden to the models and practices of the past and more willing to embrace new strategies, technologies and approaches. We need to support these new leaders, welcome their creativity, and empower them to reshape the field in ways that we cannot yet envision (Kriesberg, 2009).

Colleges and universities are, in large part, responsible for developing American society's civic health (Astin, 1993; Posner, 2004). Higher education plays a major part in shaping the quality of leadership in modern American society (Astin \& Astin, 2000; Carnegie Foundation, 2005). The purpose of higher education is to empower students to be future leaders (Johnson, 2000; Komives, Lucas, \& McMahon, 2007). This research proposes that the type of leadership Planning programs should focus on is transformational leadership.

Planning students should be provided an educational experience which teaches students how to engage community members in learning about and understanding community issues, and the economic, social, environmental, political, psychological, and other impacts associated with developing a comprehensive, collaborative, sustainable community plan.

\section{Community-Engaged Learning}

Community-engaged learning has long been viewed as a means for developing students to be socially responsible citizens. Dewey $(1898,1916)$ believed that students would learn more effectively and become better citizens if they engaged in structured, democratic, ethics-driven learning opportunities. "Citizenship education is a comprehensive approach aimed at instilling in students the knowledge, skills, and dispositions necessary for effective civic participation” (Maine Citizenship Education Taskforce, 2006). Differently, community service and service-learning implies performing sporadic services for a community partner, rather than developing a mutually-beneficial long-term working relationship.

Community-engaged learning is one way of "delivering" citizenship education. It is a pedagogy that integrates community engagement with academic study to enrich learning, teach civic responsibility, and strengthen communities. Students are waiting for the opportunity to demonstrate their leadership potential (Cress et al., 2001). "Project-based service learning emphasizes educational opportunities that are interdisciplinary, student-centered, collaborative, and integrated with real world issues and practices” (Bradford, 2005). Leadership, specifically transformative leadership, is one of the ideals advanced in this type of pedagogy. Community-engaged learning "connects people to their community. [It] provides an opportunity to work together in solving community problems and improving the quality of life" (Alliance for Service-Learning Standards Committee, 1995: p. 1). Community-engaged learning connects the students to the dynamic environment of living communities.

Community-engaged learning is a transformative process with roots in social reconstructionism. "Problemposing education bases itself on creativity and stimulates true reflection and action upon reality, thereby responding to the vocation of men as beings who are authentic only when engaged in inquiry and creative transformation” (Freire as cited in Darder, Baltodano, \& Torres, 2003: p. 66). Planning students should be exposed to these ideas in their curriculum if we expect them to understand their dual roles in society-Planner and citizen.

Experiential, project-based, community-engaged pedagogy is the ideal method for students to use in planning for sustainable communities. Critical pedagogy is referenced for its desire to "create consciousness" (Freire in Darder, Baltodano, \& Torres, 2003: p. 354). It is a liberatory form of education and one that lends itself to community planning, leadership, and citizenship. Project-based service learning has also been a motivating factor for students to engage in their academics.

"Students learn best when they are actively engaged in the learning process" (Brown, 1998: p. 2). Laursen (2003: p. 241) reinforces its value by saying that "service learning activities promote students' self-esteem, develop higher order thinking skills, empathy, personal values, awareness, self-confidence, and social responsibility”. This emphasizes the principles of socially responsible citizens, community leaders, and planning ideals.

The first step in this teaching and learning process is to develop awareness. Do students know about community issues, initiatives, activities and events? More importantly, do the professors teach these to the students? It is the responsibility of both to know that there is more going on than what meets the eye. The Planner will typically look at the built environment, but must also be conscious and aware of the social and political environ- 
ment.

Knowing the community system is being informed, and it requires research and networking to be aware of different perspectives on community issues. A Planner wants to have diversity of perspective, but also respect for the context and civic infrastructure that will ultimately be responsible for sustaining the community. This looks at the capacity of communities to comprehensively examine its quality of life system and become informed about the issues, assets and capacity to "solve the problem.” Because Planners are driven to solve problems, this creates a bridge to involvement.

Involvement takes many forms. It can be attending community meetings, showing up for events, participating in projects that improve quality of life, beautification, volunteering, or giving service to the community in some way. This also includes deliberate course offerings in the Planning curriculum that provide these kinds of opportunities. Different types of courses like this exist; project-based learning, community-based courses, service learning and, most notably, those courses that go the extra step by providing an action-research, participatory element that creates a dialogue between community/partner for a mutually beneficial solution that focuses on sustainability. The community-engaged course aims to incorporate all of the elements of the continuum of making students aware, informed and involved, but it takes it to the next step; being engaged means becoming a part of the community. This goes beyond a working partnership.

The immersion stage of the learning continuum of community-engaged learning is what defines its significance. This is when Planning students engage. This is where the students learn how to work on a team, empower others with their skills, remind them of their assets to sustain the momentum, and be cognizant that this process will affect the sustainability of the community.

The Planner's job is to work with the community, to facilitate the process and implement the vision of the community, and then for the community to be empowered with the skills and assets to sustain community development efforts. It is not all bricks and mortar, nor is it all about people. It is about both, but with a focus on the ethical imperative of Planners to help develop the social and physical infrastructures that will ultimately lead to sustainable communities. Planning students must learn this within the community, not from the outside looking in. This produces engaged citizens participating with their neighbors in solutions for their quality of life. It provides the basis for a sustainable community.

\subsection{Transformational Leadership}

Transformational leaders frame holistic issues, set new goals and direction, create meaning and manage creative conflict. These leaders promote organizational learning, create a context for dialogue, manage paradigms and create commitment through shared values. Transformational leaders are self-confident and assertive. They seize opportunities, tolerate risk and use "systems thinking” (Senge, 1990). These are also the characteristics Planners are expected to possess, leading us to ask how students are learning leadership skills.

Transformational leadership is an approach that creates valuable and positive change in the followers with the end goal of developing followers into leaders, "transforming” others into a collective system of complimentary functions supporting the quality of life in communities (Burns, 1978). Planners are expected to behave in this way, according to both the principles of Planning, and as members of the higher education system. This type of leader, defined in this research as a Transformational Planner, is one who challenges community members to take ownership of the community system. Thus, the role of the Transformational Planner is to support the community system.

Transformational leadership is defined as a leadership approach that causes change in individuals and social systems (Bass, 1990; Burns, 1978). In its ideal form, it creates valuable and positive change in the followers with the end goal of developing followers into leaders. Enacted in its authentic form, transformational leadership enhances the motivation, morale and performance of his followers through a variety of mechanisms. These include connecting a follower's sense of identity and self to the mission and the collective identity of the organization; being a role model for followers that inspires them; challenging followers to take greater ownership for their work, and understanding the strengths and weaknesses of followers, so the leader can align followers with tasks that optimize their performance.

According to Burns (1978), the transformational approach creates significant change in the life of people and organizations. It redesigns perceptions and values, and changes expectations and aspirations of the system. Transformational leaders are idealized in the sense that they are a moral exemplar of working towards the bene- 
fit of the team, organization and/or community. Assumptions about transformational leaders are that people will follow a person who inspires them, that a person with vision and passion can achieve great things, and that the way to get things done is by injecting enthusiasm and energy.

Transformational leadership starts with the development of a vision, a view of the future that will excite and convert potential followers. This vision may be developed by the leader, by the senior team or may emerge from a broad series of discussions. The important factor is the leader buys into it. The next step is to constantly sell the vision. This takes energy and commitment. The transformational leader thus takes every opportunity and will use whatever works to convince others to climb on board. The route forward may not be obvious and detailed, but with a clear vision, the direction will always be known. Thus, finding the way forward can be an ongoing process of course correction and the transformational leader will accept that there will be failures along the way (Burns, 1978).

Transformational leaders are always visible and can be relied on. They show by their attitude and actions how everyone else should behave. They also make continued efforts to motivate and rally their followers, constantly doing the rounds, listening, soothing and enthusing. It is their unswerving commitment as much as anything else that keeps people going, particularly through the darker times when some may question whether the vision can ever be achieved. If the people do not believe that they can succeed, then their efforts will flag. Transformational leaders seek to infect and re-infect their followers with a high level of commitment to the vision (Bass, 1985). Some may liken this to the philosophy behind community leadership, another to sustainable community development practice.

This type of leader balances attention between action that creates progress and the mental state of followers. Perhaps more than in other approaches, transformational leaders are people-oriented and believe that success comes through deep and sustained commitment. While the transformational leader seeks overtly to transform the system, there is also a tacit promise to stakeholders that they also will be transformed in some way; stakeholders are the products of the transformation (Bass, 1985).

Leadership, then, is assessed in this research through the use of the Student Leadership Practices Inventory (S-LPI) (Kouzes \& Posner, 2003; Posner, 2004), which is appended to this paper. According to Posner (2009), the S-LPI was designed to identify specific behaviors and actions that students report using when they are at their personal best as leaders (Kouzes \& Posner, 2008; Posner \& Brodsky, 1992). These behaviors are categorized into five leadership practices: Modeling the Way, Inspiring a Shared Vision, Challenging the Process, Enabling Others to Act, and Encouraging the Heart (2008). Using Kouzes and Posner's assessment of leadership, it is possible to capture specific leadership characteristics of Planning students.

\section{Student Leadership Development}

Scholars say that leadership, like any other skills, needs to be learned and practiced (Komives, Lucas, \& McMahon, 2007). Astin and Astin (2000) offer a lens to view the idea of leadership development for the purposes of this research by saying "leadership can be more an active tool than a passive lens" (p. 6). This idea presents leadership as an action rather than just a frame of reference; that is, leadership should be used as a core ingredient of learning.

There is evidence that student leadership has positive impacts on career, academic, and personal development (Logue et al., 2005; Cress et al., 2001; Tomlinson-Clarke \& Clarke, 1994). However, few studies have examined leadership related to the persistence of leadership, namely the impact it has upon students' membership in society as citizens engaged in creating and maintaining healthy, sustainable communities. "Despite the plethora of leadership programs scattered across college campuses, scant empirical investigation has been conducted into the benefits of such educational efforts" (Posner, 2009: p. 551).

The goal here is to present support for a Planning curriculum that incorporates leadership development through community-engaged learning by showing that students who have more community-based learning experiences are better prepared to build healthy and sustainable communities.

\section{Research Methodology}

The methodology used for this research is the case study. Case study research excels at creating an understanding of a complex issue or object and can extend experience or add strength to what is already known through previous research (Tellis, 1997). Social scientists, in particular, have made wide use of this qualitative research 
method to examine contemporary real-life situations and provide the basis for the application of ideas and extension of methods. Robert K. Yin (1984: p. 23) defines the case study research method as an "empirical inquiry that investigates a contemporary phenomenon within its real-life context; when the boundaries between phenomenon and context are not clearly evident; and in which multiple sources of evidence are used".

Construct validity has been a source of criticism in case study research because of potential investigator subjectivity. Yin (1994) proposes three remedies to counteract this: using multiple sources of evidence, establishing a chain of evidence, and having a draft case study report reviewed by key informants. This research had a key informant reviewing the draft case study report. One last remedy to counteracting potential investigator subjectivity is to have an impartial statistician verify the data and its treatment. This remedy was also used.

This research looks at the correlation between two variables, leadership and community engagement, not at a causal relationship. Therefore, internal validity is not an issue. However, external validity warrants mention as it deals with knowing whether the results are generalizable beyond the immediate case. Because this is a case study, the results are significant to the specific population, but could be replicated using a larger sample of Planning programs. Some of the criticism against case studies in this area relates to single-case studies. However, that criticism is directed at the statistical, and not the analytical, generalization that is the basis of case studies. Reliability is achieved in many ways in a case study, with one of the most important being the development of the case study protocol (Tellis, 1997), as has been done in this research.

\subsection{Sample}

The sample used for this research is upper-level Planning undergraduate students in one four-year public research-intensive university, as defined by the Carnegie Foundation (2011), in an urban metropolitan area of the Midwest. The population of interest is Planning students in their fourth and fifth years of the program. Generally, the better respondents know the researcher, the better the response rate. Acceptable response rates vary by how the survey is administered, but online surveys show a good response rate of 30\%. 28 (34.5\%) completed surveys $(n=28)$ were analyzed for this research.

\subsection{Instrumentation}

As noted above, leadership is assessed through the use of the Student Leadership Practices Inventory (S-LPI) (Kouzes \& Posner, 2003; Posner, 2004). According to Posner (2009), the S-LPI was designed to identify specific behaviors and actions that students report using when they are at their personal best as leaders (Kouzes \& Posner, 2008; Posner \& Brodsky, 1992). These behaviors are categorized into five leadership practices: Modeling the Way, Inspiring a Shared Vision, Challenging the Process, Enabling Others to Act, and Encouraging the Heart (2008). Respondents are asked to consider how frequently they engage in each of the behaviors using five-point Likert-type scales, with 1 indicating rarely or seldom and 5 indicating very frequently or almost always. This instrument collects self-reported data.

Identified as practices common to successful leaders in corporate, government, and not-for-profit organizations (Posner, 2009), these leadership practices and behaviors have been shown to correspond well with the developmental issues of importance for college students (Brodsky, 1988). In developing the original version of the Leadership Practices Inventory, Kouzes and Posner (2007) collected case studies from over 1,200 managers about their "personal best experiences" as leaders. Content analyses of these case studies suggested a pattern of behaviors used by people when they were most effective as leaders. The development of a student version of the instrument followed the same case-study approach to investigate whether the leadership behaviors of college students were comparable with those of managers (Brodsky, 1988; Posner \& Brodsky, 1992).

Studies using the S-LPI have shown strong internal reliability across a variety of student populations, with Cronbach's alpha scores ranging from .55 to .83 (Posner, 2004). The Cronbach's alpha scores for each leadership practice in this study, using the sample of seniors, was .66 for modeling, .74 for inspiring, .63 for challenging, .72 for enabling, and .80 for encouraging. Earlier analysis of S-LPI scores with the Crown-Marlowe Social Desirability Index "confirms previous findings that indicated tests of social desirability bias were not statistically significant” (Walker, 2001: p. 58). Test-retest reliability of the S-LPI over a 10-week period was demonstrated as statistically significant ( $p<.001$ ), with correlations exceeding 0.51 (Pugh, 2000).

The S-LPI demonstrates good validity with consistent relationships found with various measures of effectiveness, as reported across multiple constituencies, and is robust across different collegiate student populations 
such as fraternities, sororities, residence halls, orientation programs and academic disciplines (Arendt, 2004; Posner, 2004). The S-LPI has demonstrated relative independence from such demographic factors as gender, age, ethnicity, GPA, year in school, or academic major (Endress, 2000; Posner, 2004; Posner \& Brodsky, 1993; Posner \& Rosenberger, 1997; Pugh, 2000; Wilcox, 2004).

This research also examines Planning students' frequency and types of community engagement experiences. This information is collected by use of an additional question on the survey, independent of the S-LPI. This question asks students to identify how frequently they participate in co-curricular and extra-curricular community engagement activities, and what those experiences are. The options include:

- Academic clubs, groups, discussions or associations;

- Community councils, groups, clubs or associations;

- Faith-based membership (attending faith-based events such as worship, listening to religious speakers, attending faith-based festivals, or religious discussion groups);

- Community service (volunteering to assist a neighborhood or organization with a project or service);

- Community-based coursework (classes or projects working in partnership with a neighborhood or organization), and

- Open-ended response option for experiences not listed.

These community engagement experiences have been validated by two experts in community engagement.

Five demographic questions are asked of students, independent of the S-LPI—age, class (first year, second year, sophomore, graduate, etc.), ethnicity, gender and enrollment status (part-time, full-time), but this is for exploratory purposes only. It should be noted that "the S-LPI has demonstrated relative independence from such demographic factors as gender, age, ethnicity, GPA, year in school, or academic major” (Posner, 2009: p. 555).

The S-LPI provides a snapshot of the leadership characteristics of Planning students in this program, but the additional questions about participation in community engagement activities are what sets this research apart. Not only is it learned if Planning students display high levels of transformational leadership behaviors, but the frequency and types of community engagement activities Planning students participate in are examined.

\subsection{Treatment of the Data}

The results of the survey are shown using frequency distributions. The S-LPI consists of 30 descriptive statements about leadership behaviors, and respondents are asked to indicate how frequently they engage in each one. Six behaviors (statements) are used to measure each one of the five leadership practices, with scores ranging from a low of 6 to a high of 30. The publisher provides the scoring rubric. Higher scores on the leadership practices indicate greater actual use or engagement of the leadership behaviors. The S-LPI allows the frequency to be seen with which Planning students use transformational leadership behaviors, and the practices of leadership they are using. The responses to the S-LPI enable the first research question to be examined: Are Planning students becoming transformational leaders? The survey asks students to list the "group" referenced when responding to these questions. A list of the qualitative responses is provided.

The second question studied is if there is a relationship between community engagement experiences and leadership behaviors. The first step to answering this question is to analyze the community engagement experiences. The analysis used is also frequency distribution. Next, the correlation between the frequency of Planning students engaging in leadership behaviors and the frequency Planning students participating in community engagement experiences is examined.

The relationship between leadership and community engagement is analyzed using the Pearson ProductMoment Correlation Coefficient (r). The correlation coefficient is a measure of the degree of linear relationship between two variables, usually labeled $\mathrm{X}$ and $\mathrm{Y}$. In this case, $\mathrm{x}$ is the average leadership practice score, and $\mathrm{y}$ is community engagement activity score. In correlation analysis, the emphasis is on the degree to which a linear model may describe the relationship between two variables and the interest is non-directional, or does not look at cause. The relationship is the critical aspect.

\section{Findings, Conclusions and Implications}

The demographic characteristics are: age, program year, race/ethnicity, gender, and enrollment status. The average age of the sample is 23 , but the most frequently occurring (mode) is 21 . The majority of respondents are seniors, i.e., fifth year students (60.7\%). Fourth year students are 25\%. Third year students make up the remain- 
ing $14.3 \%$. White students comprise $96 \%$ of respondents. There are two ethnicities represented, black and white. The majority of the sample is male (60.7\%). $96 \%$ of respondents are full-time students.

\subsection{Research Question Results}

\subsubsection{Planning Students as Transformational Leaders}

Are Planning students, then, becoming transformational leaders? The following data are based on the responses to the survey:

- The majority of students fall in the low category for modeling the way;

- The majority of students fall in the low rating for inspiring a shared vision;

- The majority of students fall in the moderate rating for challenging the process;

- The majority of students fall in the low rating for enabling others to act;

- The majority of students fall in the low category for encourage the heart;

- The majority of students had no high level of leadership scores;

- The majority of students fell in at least one moderate level of leadership score, and

- The majority of students fell in the four or zero low level of leadership score.

Based on these data, Planning students display a low level of leadership. The leadership practice most often used by Planning students is enabling others to act, followed by challenging the process and inspiring a shared vision practices. Planning students said Planning classes and the Planning Student Organization were the settings referenced when assessing their leadership behaviors. This reveals that the leadership behaviors reported by students were based upon Planning program related activities.

\subsubsection{Community Engagement and Transformational Leadership}

Is there a correlation between community engagement experiences and transformational leadership behaviors? The following data are based upon the responses to the survey:

- The majority of students participate in academic clubs, discussion groups, or associations rarely or seldom;

- The majority of students participate in community councils, civic groups, political clubs or associations once in a while;

- The majority of students participate in faith-based clubs, groups or associations rarely or seldom;

- The majority of students participate in ongoing volunteer or community service commitments very often, and

- Students participate in community-based coursework in three levels; rarely or seldom, sometimes or very often.

These data tell us that Planning students participate in ongoing volunteer or community service commitments most often, followed by community-based coursework. This leads us to believe the Planning curriculum provides students with an opportunity to engage in community engagement through coursework offered. Although it cannot be affirmed that the Planning program is the source for students participating in ongoing volunteer or community service commitments, it can be affirmed that this is the most frequent community engagement activity Planning students are a part of.

\subsection{Study Hypothesis Results}

Hypothesis: There is a correlation between Planning students with high levels of leadership behaviors and high levels of community engagement. The following data are generated using the survey responses:

1) There is a positive correlation between modeling the way scores and community engagement $(r=.45)$;

2) There is a positive correlation between inspiring a shared vision scores and community engagement ( $r$ $=.64$ );

3) There is a positive correlation between challenge the process scores and community engagement $(r=.57)$.

4) There is a positive correlation between enabling others to act scores and community engagement $(r=.42)$, and

5) There is a positive correlation between encouraging the heart scores and community engagement $(r=.47)$.

From these data, there is a positive correlation between average leadership practice scores and community engagement activities $(r=.57)$. Moreover, these data tell us that Planning students' leadership behavior is associated with their level and type of community engagement. The data also tell us that Planning students show the highest correlation between leadership and community engagement in the inspiring a shared vision practice 
(albeit only at a moderate level).

Based upon the survey responses, Planning students are not displaying high levels of leadership behavior. However, there is a (positive) correlation between moderate levels of leadership and community engagement activities.

This research only examines correlation to see if there is actually a relationship between leadership and community engagement. Further research could tell us the cause of this relationship. Does leadership cause engagement, or does engagement cause leadership? This is a compelling question and should be a part of a larger discussion about educational pedagogy, namely community-engaged learning.

This research advocates for a community-engaged approach to Planning education, an approach that requires partnership between Planners and the communities they represent. Of course, this is only one perspective on how to teach a Planner, but it is one that ensures Planning students are aware of sustainable processes to build and maintain communities from the inside out. This is more than a technical, skills-based approach to their education. Rather, it provides a balance of the social and technical skills Planners need to know in order to fulfill their obligations to the public. The burning question is if there were more Transformational Planners, would we have more sustainable communities?

\section{References}

Addams, J. (1902). Democracy and Social Ethics. Chicago, IL: Hull House.

Alliance for Service-Learning Standards Committee (1995). Standards of Quality for School-Based and Community-Based Service-Learning. Alexandria, VA: Alliance for Service-Learning in Educational Reform.

American Institute of Certified Planners (2005) Code of Ethics. http://www.planning.org/ethics/ethicscode.htm

American Planning Association (2010). www.planning.org

Arendt, S. (2004). Leadership Behaviors in Undergraduate Hospitality Management and Dietetics Students. Unpublished Doctoral Dissertation, Ames, IA: Iowa State University.

Association of Collegiate Schools of Planning (2011). www.acsp.org

Astin, A. W., \& Astin, H. S. (2000). Leadership Reconsidered: Engaging Higher Education in Social Change. Battle Creek, MI: W.K. Kellogg Foundation.

Astin, A. W. (1993). What Matters in College: Four Critical Years Revisited. San Francisco: Jossey-Bass.

Bass, B. M. (1985). Leadership and Performance beyond Expectation. New York: Free Press.

Bass, B. M. (1990). From Transactional to Transformational Leadership: Learning to Share the Vision. Organizational Dynamics, 18, 19-31. http://dx.doi.org/10.1016/0090-2616(90)90061-S

Block, P. (2008). Community. The Structure of Belonging. San Francisco, CA: Berrett-Kohler Publishers, Inc.

Bradford, M. (2005). Motivating Students through Project-Based Service Learning. THE Journal, 32, $29-30$.

Brodsky, B. (1988). Development of a Modified Version of the Leadership Practices Inventory for Use with College Students. Unpublished Master's Thesis, San Jose, CA: San Jose State University.

Brown, B. L. (1998). Service Learning: More than Community Service. ERIC Digest No. 198. Columbus, OH: Clearinghouse on Adult, Career, and Vocational Education.

Burns, J. M. (1978). Leadership. New York: Harper \& Row.

Carnegie Foundation (2005). Higher Education: Civic Mission and Civic Effects. A Report by the Carnegie Foundation for the Advancement of Teaching and CIRCLE.

http://classifications.carnegiefoundation.org/lookup_listings/view_institution.php?unit_id=201885\&start_page=institution. php\&clq $=\{\% 22$ first_letter $\% 22 \% 3 \mathrm{~A} \% 22 \mathrm{U} \% 22\}$

Cress, C. M., Astin, H. S., Zimmerman-Oster, K., \& Burkhardt, J. C. (2001). Developmental Outcomes of College Students’ Involvement in Leadership Activities. Journal of College Student Development, 42, 15-27.

Darder, A., Baltodano, M., \& Torres, R. D. (2003). The Critical Pedagogy Reader. New York, NY: Rutledge Falmer.

De Toqueville, A. (1838). Democracy in America. London: Saunders and Otley.

Dewey, J. (1898). The Study of Ethics. Ann Arbor, MI: George Wahr.

Dewey, J. (1916). Democracy and Education: An Introduction to the Philosophy of Education. New York: Macmillan.

Eddy, J. P., Murphy, S. D., Spaulding, D. J., \& Chandras, K. V. (1997). 21st Century Leadership Practices Needed for Higher Education. Education, 117, 327-331.

Endress, W. L. (2000). An Exploratory Study of College Student Self-Efficacy for Relational Leadership: The Influence of 
Leadership Education, Cocurricular Involvement, and On-Campus Employment. College Park, MD: University of Maryland.

Everyday Democracy (2011). Tips for Successful Community Planning.

Fawcett, S. B., Paine-Andrews, A., Francisco, V. T., Schultz, J. A., Richter, K. P., Lewis, R. K., Williams, E. L., Harris, K. J., Berkley, J. Y., Fisher, J. L., \& Lopez, C. M. (1995). Using Empowerment Theory in Collaborative Partnership for Community Health and Development. American Journal of Community Psychology, 23, 677-697. http://dx.doi.org/10.1007/BF02506987

Hergert, L. F. (2002). Snapshots of Service-Learning: Factors for Its Integration and Sustainability in School Districts. Educational Horizons, 80, 195-199.

Hillier, J., \& Healy, P. (2008). Critical Essays in Planning Theory, Vol. 1. Foundations of the Planning Enterprise. Surrey, $\mathrm{UK}$ : Ashgate.

Iannacone, L., \& Lutz, F. W. (1994). The Crucible of Democracy: The Local Arena. In J. D. Scribner, \& D. H. Layton (Eds.), The Study of Educational Politics: Politics of Education Association Yearbook 1994 (pp. 39-52). Washington, DC: The Falmer Press.

Jacques, L. J. (1999). Applying Deming's Theory to Community Issues. Downloaded from the Community Quality Electronic Network Library. http://deming.eng.clemson.edu/pub/cqen/files/

Johnson, C. W. (2000). Exploring Leadership Development for College Students Who Want to Make a Difference. NASPA Journal, 38, 143-147.

Kennedy, M. (1996). Transformative Community Planning: Empowerment through Community Development. Prepared for the 1996 Planners Network Conference.

http://www.plannersnetwork.org/magazine-publications/case-studies-and-working-papers/transformative-com munity-planning-empowerment-through-community-development/

Kennedy, M. (2009). Transformative Planning for Community Development. The Institute for Research on Labor and Employment, UCLA. http://escholarship.org/uc/item/14r1s460

Kettering Foundation (n.d.). The Higher Education Exchange. http://www.kettering.org/about_the_foundation

Komives, S., Lucas, N., \& McMahon, T. (2007). Exploring Leadership. San Francisco, CA: Jossey-Bass.

Kouzes, J. M., \& Posner, B. Z. (2003). The Leadership Challenge (3rd ed). San Francisco, CA: Jossey-Bass.

Kouzes, J. M., \& Posner, B. Z. (2007). The Leadership Challenge (4th ed.). New York: John Wiley and Sons.

Kouzes, J. M., \& Posner, B. Z. (2008). To Lead, Create a Shared Vision. Harvard Business Review, 20-21.

Kriesberg, J. (2009). A 21st Century Vision for Community Development. Shelterforce: The Journal of Affordable Housing and Community Building. National Housing Institute.

http://www.shelterforce.org/article/1767/a_21st_century_vision_for_community_development/P1/

Kubisch, A. (1996). Comprehensive Community Initiatives: Lessons in Neighborhood Transformation. Shelterforce: The Journal of Affordable Housing and Community Building. National Housing Institute. http://www.nhi.org/online/issues/85/compcominit.html

Laursen, E. K. (2003). Creating Community through Service. Reclaiming Children and Youth, 11, 240-241.

Local Initiatives Support Corporation. Building Sustainable Communities. http://lisc.org/section/ourwork/sc

Logue, C. T., Hutchens, T. A., \& Hector, M. A. (2005). Student Leadership: A Phenomenological Exploration of Postsecondary Experiences. Journal of College Student Development, 46, 393-408. http://dx.doi.org/10.1353/csd.2005.0039

Maine Citizenship Education Taskforce (2006). http://www.maine.gov/education/mecitizenshiped/campaign/whatis.html

Marcuse, P. (1976). Professional Ethics and Beyond: Values in Planning. Journal of the American Institute of Planners, 42, 264-274. http://dx.doi.org/10.1080/01944367608977729

Marcuse, P. (1989). Who/What Decides What Planners Do? Journal of the American Planning Association, 55, 79-81. http://dx.doi.org/10.1080/01944368908975405

Marcuse, P. (2010). Changing Times, Changing Planning: Critical Planning Today. Progressive Planning, 182, 13-16.

Nagy, B. A. (2012). Are Community Planning Students Becoming Transformational Leaders? A Case Study. Saarbrücken: Lambert Academic Publishing.

National Civic League (2007). http://www.allamericacityaward.com/about-ncl/

Planning Accreditation Board (2006). The Accreditation Document: Criteria and Procedures of the Planning Accreditation Program.

Posner, B. Z., \& Rosenberger, J. (1997). Effective Orientation Advisors Are Leaders too. NASPA Journal, 35, 46-56.

Posner, B. Z. (2004). A Leadership Development Instrument for Students: Updated. Journal of College Student Development, 
45, 443-456. http://dx.doi.org/10.1353/csd.2004.0051

Posner, B. Z. (2009). A Longitudinal Study Examining Changes in Students’ Leadership Behavior. Journal of College Student Development, 50, 551-563. http://dx.doi.org/10.1353/csd.0.0091

Posner, B. Z., \& Brodsky, B. (1992). A Leadership Development Instrument for College Students. Journal of College Student Development, 33, 231-237.

Posner, B. Z., \& Brodsky, B. (1993). The Leadership Practices of Effective RAs. Journal of College Student Development, 34, 300-304.

Posner, B. Z., \& Brodsky, B. (1994). Leadership Practices of Effective Student Leaders: Gender Makes No Difference. NASPA Journal, 31, 113-120.

Pugh, D. (2000). College Student Leadership Development: Program Impact on Student Participation. Unpublished Doctoral Dissertation, Athens: University of Georgia.

Putnam, R. D. (2000). Bowling Alone: The Collapse and Revival of American Community. New York: Simon \& Schuster.

Senge, P. (1990). The Fifth Discipline: The Art and Practice of the Learning Organization. New York: Doubleday.

Sussman, A. (2011). Brainy Boston: Edgy, Future-Oriented Research Is the Rule at Local Universities. Planning, 77, 30-33.

Swisher, M. E., Rezola, S., \& Sterns, J. (2009). Sustainable Community Development. Publication \#FCS7213-Eng, Gainesville, FL: University of Florida IFAS Extension, Electronic Data Information Source.

Talcott, W. (2005). Modern Universities, Absent Citizenship? Historical Perspectives. CIRCLE Working Paper 39, College Park, MD: University of Maryland.

Tellis, W. (1997). Introduction to Case Study [68 paragraphs]. The Qualitative Report, 3. http://www.nova.edu/ssss/QR/QR3-2/tellis1.html

Tomlinson-Clarke, S., \& Clarke, D. (1994). Predicting Social Adjustment and Academic Achievement for College Women with and without Precollege Leadership. Journal of College Development, 35, 120-124.

Walker, J. (2001). Leadership Development of Students Engaged in Experiential Learning: Implications for Internship Programs in Textile and Apparel. Unpublished Doctoral Dissertation, Greensborough: University of North Carolina.

Wilkins, K. A., Parker, J., \& Dale, T. (2008). Cultivating Citizens through Community Outreach: Engendering Civic Awareness in a University Youth Program. University of Southern California Upstate Undergraduate Research Journal, 1, 52-56.

Yin, R. (1994). Case Study Research: Design and Methods (2nd ed.). Beverly Hills, CA: Sage Publishing.

Yin, R. K. (1984). Case Study Research: Design and Methods. Newbury Park, CA: Sage.

Youniss, J., McLellan, J. A., \& Yates, M. (1997). What We Know about Engendering Civic Identity. American Behavioral Scientist, 40, 620-631. http://dx.doi.org/10.1177/0002764297040005008 
Scientific Research Publishing (SCIRP) is one of the largest Open Access journal publishers. It is currently publishing more than 200 open access, online, peer-reviewed journals covering a wide range of academic disciplines. SCIRP serves the worldwide academic communities and contributes to the progress and application of science with its publication.

Other selected journals from SCIRP are listed as below. Submit your manuscript to us via either submit@scirp.org or Online Submission Portal.

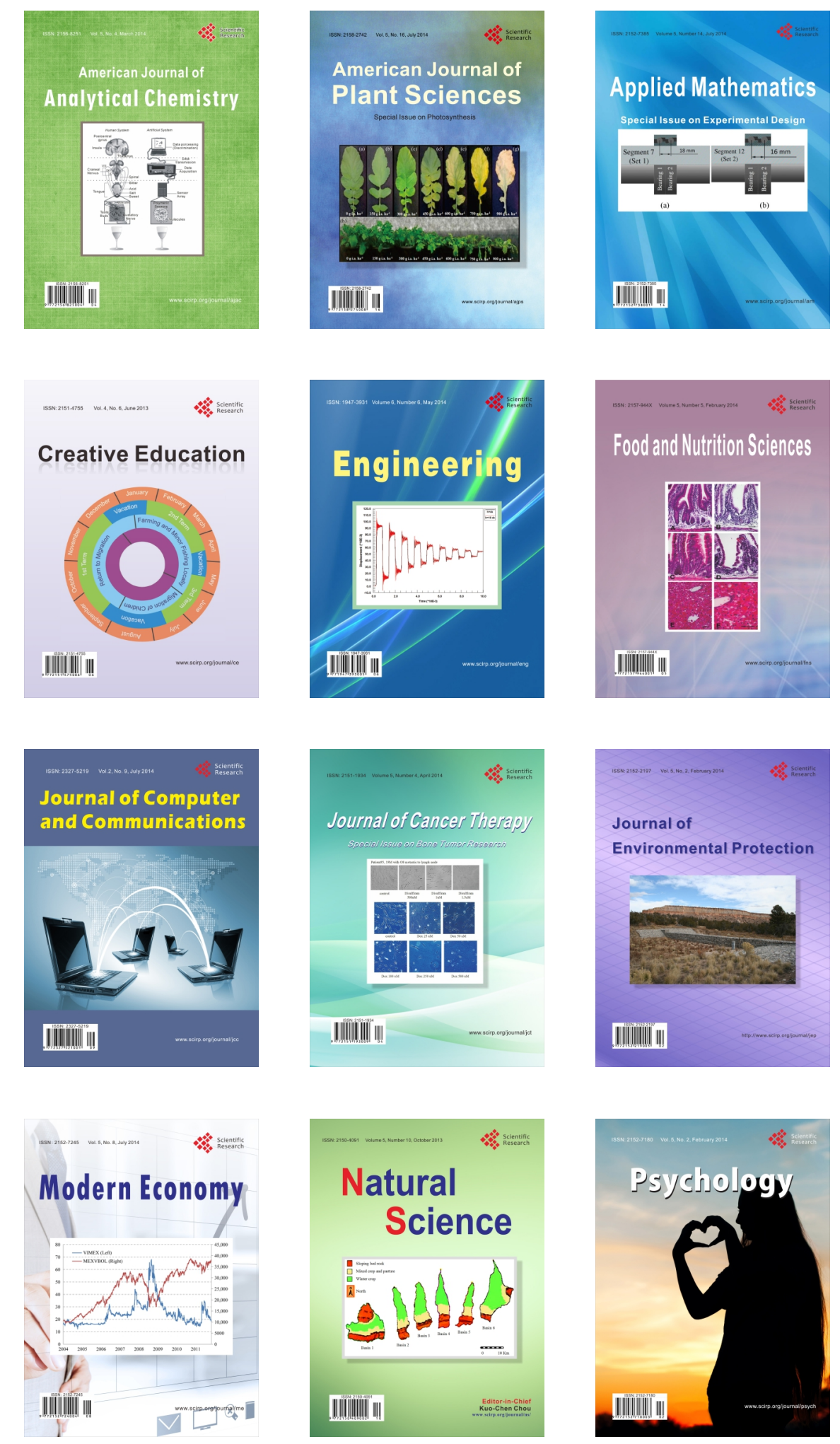